New Zealand journal of industrial relations, 1987, 12, 13-22

\title{
The revival of China's organised Labour 1973-86
}

\author{
Richard Morris*
}

This paper analyses the development and role of Chinese trade unions in the post Cultural Revolution era. The growth of organised labour from virtual dissolution in the late 1960 s is charted at national and enterprise level. The text outlines significant post 1973 trade union involvement in industrial welfare, education and productivity. The current status of wage fixation and grievance handling in Chinese labour relations is also explored. The paper concludes by appraising Chinese trade unionism and its relationship to industrial policy in recent times.

\section{Introduction}

In common with major Western economies in the late 1970 s and early 1980 s, China experienced the development of decentralising policies which gave greater weight to market forces as opposed to the centrally planned economy. The Western experience has been that the resurgence of market relations has been accompanied by government anti-labour policies which attempted to curb and remove support from trade unions. Without pushing parallels too far, the reverse has been the case in China. Although the "market" has been enhanced by measures to decentralise wages and prices, and by the expansion of enterprises outside the state sector, at the same time trade unionism as a formal institutional entity has prospered with government patronage.

This paper aims to explain the growth and role of Chinese trade unions in the 1973-86 era in a new policy context which promoted the "market", and can be viewed as a further post Cultural Revolution phase in the cyclical oscillation of "moderate", economic growth oriented pragmatism and "radical" revolution in industrial policy (Andors, 1977, p. 281).

In terms of numerical expansion, the Chinese labour movement grew to unprecedented levels in the 1973-85 era. In 1982, 73.3 million trade union members were claimed, over 85 percent of the total workforce in the state sector and 75 percent of the total urban workforce of $110,000,000$. This represented a 42 percent increase over the claimed membership figure for 1979 (British Broadcasting Corporation 21 October 1983; Beijing review, 13 February, 1984, p. 21).

Qualitatively, by 1983, it included not only the labour aristocratic workers of the major industrial belts, but also newcomers to the cause of trade unionism, humble weavers from the sheds of Inner Mongolia and the Tibetan Trades Council, headed by a former monastery slave (Workers daily, 6 January 1982; BBC, 26 October 1978).

On these terms the Chinese labour movement has grown to be the second largest in the world, out-stripped only by the USSR's 106 or more million trade union members representing almost 99 percent of the workforce, but easily leaving behind not only in numerical size but also in membership density the trade union movements of the industrial west where ratios of organised labour to the total workforce rarely exceeded 60 percent in the late 1970s and early 1980s (Kahan \& Ruble, 1979, p. 71). China's instant trade union membership also dwarfed that of the other giant less developed country, India, where problems of methodology and reporting make accurate statistics exceptionally difficult, but

Senior Lecturer. Department of Industrial Relations. The University of Sydney.

The author wishes to thank the Journal's anonymous referees and Professor George Strauss for helpful comments. 
where at an educated guess, trade union membership density is approximately 30 percent or about 5 million members in the narrowly defined "industrial" workforce eligible for trade union membership (Crouch, 1979, p. 293).

After 1978, Chinese trade union membership was formally reorganised into a number of restored institutions which at the analytical level conformed to the "dual-functioning model" imported in part from the USSR and progressively elaborated on for a period after the VIth All China Labour Congress held at liberated Harbin in Manchuria in August 1948, which had established the trade unions in the post revolutionary state (Henley \& Chen, 1981 p. 81; Littler, 1983, p. 31).

In essence, the "dual functioning" model consisted of industrial unions such as the All China Educators' Union coupled with geographically based delegate councils at municipal, provincial and regional levels. At the apex was the All China Federation of Trade Unions (ACFTU), a national delegate council with a permanent executive and secretariat which had been dissolved during the Cultural Revolution (To, 1983, p. 50).

The post 1978 "dual-functioning" structure reflected the traditional communist organisational forms. The "industrial" union had been hallowed as the proper form of worker organisation since the formation of communist unions. The system of delegate councils reproduced the approved structures of other representative and popular institutions. Unlike the longtern situation in the USSR however, these bodies in China did not in the half decade or so after 1978 develop identifiable contractual relationships with the enterprises and the ministries who employed their affiliated memberships on the shopfloor. This informality may not continue to be always the case, given the growth of formal contract in most spheres of Chinese business, including employment.

\section{The new beginnings of Chinese trade unionism 1973-80}

The trade unions re-emerged as a definitive entity in the climate of re-shuffling and innovation encouraged by the Post-Mao economic rationality. But Post-Cultural Revolution trade unionism in China took the shape of a bureaucracy sponsored by the state with very scarce vestiges of labour protest attached to it. The intended general function of re-organised labour was not to challenge national economic policy but to facilitate it.

Although other instruments also guaranteed employment and trade union rights, the Constitution adopted by the IXth ACFTU Congress in 1978 became the legal basis of restoration. It provided an extensive protective scaffolding of membership rights covering electoral procedures, internal appeals and grievances, and access to trade union welfare and cultural services.

The basic unit of organisation at the plant level was the primary trade union committee which was permitted to be elected in every enterprise or institution with more than 25 members. In undertakings with fewer than 25 members, workers were expected to join the nearest primary trade union organisation in a related industry or set up a joint primary organisation together with workers from other small units. In large organisations, this process was called to work in reverse with the primary trade union committee sponsoring through elections, workshop and departmental sub-committees. As in the other levels of union government, procedural provisions for committee and official elections and the regular scheduling of meetings were published (Tsien, 1979, p. 56).

With publicly authorised procedures, the re-approved status of trade unionism was made clearer. Reports of new trade union organisation and membership expansion proliferated. One former major industrial union, the All China Federation of Railway Workers' Union, held its VIIIth National Congress after a 12 year suspension in the week following the IXth ACFTU Congress (China directory, 1980, p. 398). As the work of restoration progressed, other reinstituted industrial unions held national congresses at which the publicised centrepiece was characteristically a "pep-talk" by a State Council dignitary. By June 1980, it was reported that trade union councils had been restored in all 29 provinces and that some 30,000 primary trade unions had been set up in the preceding 12 months. An increase of 22,000 in the number of cadres involved full-time in trade union work was also claimed (XUE, 1982, p. 716).

The refurbishment of the trade unions was part of the general restoration of institutional furniture which took place as the Cultural Revolution wound down. The first public indication of a new stage in the life cycle of labour organisation was a call in the Peking Daily on New Year's Day 1973 for the re-establishment of "mass-organisations", the general 
category in the organisational table of Chinese state and society in which trade unions, along with women's and youth bodies were fitted.

After the official signal, bodies calling themselves trade unions were soon identifiable on the workplace landscape, alongside party branches and revolutionary committees which had been the characteristic workplace organisation of the Cultural Revolution. Separate functions were less clearly identifiable among these organisations. Official trade union spokesmen emphasised the need to disseminate the Party line and participated in the current political campaigns such as Anti-Confucianism. Non-political trade union functions which rated official mention were employee technical and administrative training, together with nursery, sports and entertainment administration.

The process of separating out trade unions' organisations and activities from those of other bodies at work gradually accelerated. The typical Cultural Revolution labour groups, shaped to the goal of political and moral transformation, were supplanted (Hoffman, 1974, p. 133). Revolutionary committees were abolished in workplaces by the Vth National People's Congress in 1978. At the same time, the trend to professionalise management and to precisely codify managerial responsibilities placed limits on the Party's role in industrial administration as a side effect. The People's Liberation Army, which had intruded into the factories before and during the Cultural Revolution, was also well on the sidelines by now. The climate was favourable for the formulation of a specific trade union role given that other major institutions which had formerly exercised a high profile in industrial administration no longer did so.

The accelerating pace of technological and organisational change brought about by the economic reforms heightened the need for a range of employee services that would hopefully increase job satisfaction and augment worker productivity. The trade unions were in a position to supply those services as the rejection of the Cultural Revolution by the ruling "Dengists" put the temporarily eclipsed traditional institutions of the People's Republic in a more favourable light.

Suitable senior core personnel were also available who had had a background in trade union work. At least 6 known members out of 11 on the executive committee of the ACFTU in 1981 had held senior trade union office prior to 1966 and had been disgraced and rusticated during the Cultural Revolution (Bartke, 1981), The Chairman, Ni Zhi Fu, who orchestrated the IXth Congress, was a former errand boy and machine shop fitter. Obscured during the Cultural Revolution era, he was to rise to politburo membership through career ladders in the party, trade unions and PLA military reserve (Bartke, 1981, p. 274).

Many of the restored ACFTU leadership shared the same background of Cultural Revolution persecution as China's currently most powerful politician, Deng Xiao Ping, who had to a considerable extent re-formed the Liu Shao Qi clique after Liu's death in prison in 1969. The tradition of trade union work had been important to this group since Liu's reputation had been partly founded on his career as a pre-revolutionary labour militant and his honorary chairmanship of the ACFTU in the post 1949 dispensation. The posthumous exoneration of Liu by the Party Central Committee in 1980 symbolised the ascendency of policy makers oriented towards industrial and organisational development rather than rural communalism (China reconstructs, June 1980, p. 9). As long as this brand of policy held sway, the ACFTU as an official organ of the industrial workers, was likely to be favoured.

Wang Chong Lun, appointed Director of the ACFTU Production Department in 1979. exemplified the current respectability of the personnel involved in the reconstituted leadership and their link with tradition. This individual's career had been made at the Anshan Iron and Steep Company where he had been appointed chief mechanical engineer in 1978 (Bartke, 1981, p. 359). Quite apart from its economic significance, this major enterprise is honoured since its model 1961 constitution became the blueprint for subsequent Chinese labour relations in which a unitary management-worker approach to industrial administration was emphasised.

In the main, the policies of these worthies consisted of not so new wine in old bottles. The new trade unions were not a threat to marketisation and economic reform. Rather, they assisted the "human relations" function in the Chinese state enterprise. Indeed, the trade unions were financially sponsored by industry and government. Their funds were derived not only from annual membership dues of 0.5 percent of total annual income per trade union member but also a 2 percent annual per capita enterprise payroll tax and undisclosed government subsidies which financed the developing network of health care and leisure facilities (BBC, 6 August 1982). 


\section{Worker congresses}

At plant level, a variation in the new unionism was sponsored. Although the establishment of new primary trade union committees and memberships in the factories continued to be reported, the late 1970 s and early 1980 s were distinguished from the pre-1978 period by the emphasis placed on the expansion of worker congresses.

After the 1978 ACFTU National Congress, workers and staff congresses re-appeared as the basic form of workplace labour organisation under ACFTU auspices. Usually honoured more as a concept than a reality, these mass participative bodies dated back to preLiberation communist industrial organisation. Between 1957 and 1961, new regulations requiring the establishment of congresses throughout industry were published. However, the congress movement along with the ACFTU apparatus, atrophied, to be replaced by other forms of worker collectivity such as the revolutionary committees until the post 1973 period of renewal.

Constitutionally, the post 1978 congresses have been accorded powers of review, ratification and initiation. The 1981 Provisional Regulations Concerning Congress of Workers and Staff Members in State-owned Industrial Enterprises conferred the right on the congress to elect basic supervisory and senior managerial personnel including directors and to appeal management decisions to the upper echelons of the Party. In addition, the regulations stipulated congress rights to information necessary to evaluate and investigate enterprise planning and finances, to discuss production contracts, work organisation, labour allocation, plant level authorised pay adjustments, rewards and penalties including recall from office (ACFTU, March 1980).

The constitutional distinction between the workers congress and the primary trade union factory committee rested in the designation of the latter as the secretariat of the congress. However, no strict demarcation of activities between the primary trade union and the refurbished workers' congress emerged in the post restoration years. Reports of organised labour's recreational, welfare and ceremonial functions made reference to congresses and workplace trade unions as sponsors. Similarly in reported cases of grievance handling, the primary trade union, the congress and the plant party committee appeared to be involved in an ad hoc way which did not depend on adherence to a strict procedural pattern (Workers daily, 18 November 1981). Along with reports of "model" congress activity, published statistics recorded in excess of a 5 fold expansion of the congress movement, particularly in the years 1980-3. According to ACFTU figures, by 1983 congresses had been established in some 20,000 enterprises, institutions and state farms. About 15,000 factory managers and directors had been elected by congress procedures along with a total of 75,000 middle level and junior supervisory personnel (BBC, 21 October 1983).

The growth of the workers' congress movement was related to the general rehabilitation of organised labour. But at the same time specific reasons can be adduced as to why congresses were promoted as the centrepiece of the new unionism in the workplace.

On the philosophical level, there were good reasons why something like a workers congress would appeal in the intellectual climate of Chinese industrial administration during the late 1970s. The application of capitalism's technologies and hierarchical managerial techniques by the economic reformers accentuated the ideological need for a "form of democratic industrial management" which would serve as a "basic symbol to distinguish socialist industrial management and capitalist industrial management" (Guo, 1980, p. 59). Given the focus on the devolution of powers to the ordinary worker, the workers' congress potentially fitted the bill and strengthened the credibility of the nominal "ownership" of Chinese state enterprises which the workers were declared to possess. At the same time worker congresses appealed from an almost contrary perspective. A Titoist and western orientation could also be read into them.

Chinese labour theoreticians were aware that worker participation and grass roots industrial democracy enjoyed a surge of popularity as concepts and programmes in international labour circles during the era of China's new trade union growth (ibid., p. 61). ACFTU planners were not slow to align their Federation with this trend. The first speech of China's new delegate to the International Labour Conference drew attention to his Federation's "main stress" on "promoting and perfecting the functioning of workers" congresses in enterprises" (ILO provisional record, 1983).

There were also concrete pragmatic reasons why the workers' congress concept should attract the new breed of economic rationalists. Workers' congresses had potential as a novel institutional channel for whistleblowing on enterprise inefficiency and deviance. Favourable 
press mentions openly encouraged this type of public accountability. For example, one newly set up workers congress in the early days of the movement was reported to have initiated production and organisational reforms which reduced the number of managers on a state farm by one-third (Workers daily, 17 December. 1981). More recently. following the attempts of Party and Municipal authorities to restrain grade drift in the north east industrial city of Yingkou, the workers congresses in some 23 enterprises were reported to have rejected the promotion applications of 66 directors and senior managers (China daily, 27 August, 1985). Worker participation which promoted senior functionaries' conception of economic reform was to be encouraged.

The success of the workers' congress movement was not unrelated to the known partiality of Deng and his supporters to the concept as an instrument of policy. In one of the most authoritative contemporary management texts, Deng is credited with a major historical role in the promotion of congresses (Guo, 1980, p. 57). Ni Zhi Fu, who consolidated his ACFTU presidential office while the post 1978 workers congress programme got under way, was a recognised member of the "third echelon" of Dengist protegees. The tides of power, then, ran in favour of the workers' congress concept.

This is not to suggest that workers congresses were able to expand into an absolute organisational vacuum. There were countervailing pressures. Other enterprise level employee groups were in existence and were encouraged to practice forms of worker participation. Particularly in larger state enterprises a welter of production committees, operations committees and shift committees co-ordinated resources and tasks and monitored discipline and hygiene (Socialist industrial enterprise management, 1980, pp. 313-315). At the point of production, then, there were officially sponsored shopfloor work committees in place before the creation of workers congresses. In addition, in specific enterprises, although workers congresses where instituted were credited with implementing initiatives rather than primary trade union committees, in practice, an area of indeterminancy in the function of workers congresses and primary trade union committees continued.

From another direction the activities of workers congresses were subject to a certain constraint. Economic reform fostered the professionalization of management, a process symbolised by the growth of learned institutes and the state sponsorship of qualifying examinations. This new premium on specialist knowledge which extended into the personnel and labour fields did not encourage the elaboration of agendas for mass decision making by ordinary workers $(\mathrm{Ng}, 1984$, p. 70$)$.

Whether constituted as trade union committees, worker congresses, or participative management groups, the shopfloor organisations reflected the policies and campaigns of reconstituted ACFTU departments, councils and industrial unions beyond the enterprise level. These fitted into 2 broad categories: health, education and welfare and labour productivity maximisation.

\section{Health, education and welfare}

Labour protection had been central to the traditions of Chinese trade unionism. In different periods, the concept had different substantive content. Immediately after the revolution, the ACFTU expanded its role in the administration of various forms of labour insurance including injury compensation and occupational pensions. That role declined in the pre-Cultural Revolution era and was not revived beyond a claimant advisory service despite the publicly expressed willingness of the ACFTU president to assume greater responsibilities in the area (BBC, 18 October, 1983).

In the post 1978 era, unions gave greater emphasis to occupational health and safety. The ACFTU's interest can be related to the modernisation programme. One aspect of modernisation had been productivity drives which were imposed on the often technologically obsolescent and under-capitalised energy and minerals sectors. An unwanted side effect had been industrial accidents. Indeed, a number of catastrophes emphasised the problem. The 1979 Tonghua No. 2 Song Zhu Zhen coalmine explosion "killed and injured dozens" during "a high output battle" which ignored standard safety procedures (BBC, 20 February, 1980).

Even more widely publicised was the floundering of Bohai No. 2 oil rig with 72 fatalities in the same year as a result of safety violations. Since the oil industry managerial groups were under a cloud after this disaster, the ACFTU was able to present itself in a favourable light on the Bohai No. 2 investigative committee which reported to the Party Central Committee and the State Council (Xue, 1982, p. 712). 
The ACFTU role in occupational safety was duly enhanced. After 1980, besides organising its own work hazards and labour protection conferences, the ACFTU became a regular if not inevitable participant in the growing number of interministerial and bureaux committees set up to deal with the industrial safety problem.

At the same time, the ACFTU received an allotment from state labour insurance funds to administer a number of health care facilities which included the showpiece Wuxi worker sanitorium in Gansu's Lake Taihu resort (Chinese trade unions, April 1982, pp. 24-27). The operation of medical facilities was a relatively token recreation of the extensive trade union role in the post 1949 labour insurance arrangements. By 1982 trade union sanitoria claimed to have treated some 26,000 workers suffering from chronic complaints, a far smaller figure than claimed in a 1955 ACFTU announcement of health care achievements (BBC, 11 November 1982, Foreign Language Press, 1956, p. 50).

In education, trade unions were one of a number of organisations to contribute to the proliferation of new schools of management, commerce and related areas, all teaching at various levels. Between 1978-83, the establishment of 50 new ACFTU schools was reported (BBC, 21 October, 1983). At the peak in Beijing, a traditional institution, the central cadre school, was re-opened under the aegis of the ACFTU Education Department. The diet of trade union training offered to stewards and professional officials included instructions on how to organise model worker campaigns. The ideological superstructure of modernisation and economic reform was also bolstered by an increasing volume of trade union journals and tracts. The flagship "Workers' Daily" suppressed during the Cultural Revolution, recommenced as the definitive doctrinal organ and chronicle of trade union events shortly before the IXth ACFTU Congress.

Besides safety and education, a variety of activities, loosely classifiable under the welfare rubric, were performed by trade unions. In essence, these derived from the traditional provident and friendly society functions of pre-revolutionary occupational associations. These functions were uncontroversial and compatible with revolutionary objectives. Expanded during the post 1948 ACFTU consolidation as a legitimate and properly financed organ of state, and again after the 1978 restoration, welfare services represented a minimum of trade union activity and were organised at all levels.

By 1980, municipal and country trades councils were reported to have set up over 200 gymnasia and over 1500 recreational clubs (Xue, 1982, p. 809). The ACFTU Cultural Ensemble performed in factories, workmen's sanatoria and the ACFTU holiday camps for model workers. In the factories, trade unions organised credit unions. film projection teams. nursery creches, hospital visits, ceremonials for new and departing workers, tree-planting projects and co-operative purchase schemes. Indeed, a newly established plant level union committee was first likely to move in these humble directions, negotiating the use of enterprise premises for its activities and requesting toilet, transport and sporting facilities for workers
(Workers daily, 6 January, 1982).

In a sense, the welfare services

behalf of trade union members, sponsored by the ACFTU or obtained from enterprises on the network of clubs, entertainme represented fringe-benefits or payment in kind. Less tangibly. distinctive workingman's sub-culture und sports amount to an organisationally against anomie and assisted in under ACFTU auspices, which provided a bulwark particularly in the new industrial in socialising the rapidly expanding urban workforce. in part then depended on its role as a created by modernisation. The ACFTU's restoration programmes.

\section{Productivity and labour emulation}

As the "owners" of industry and as functionaries in the unitary enterprise. workers" mobilisation of workers behind goals of the central planners is supposedly axiomatic. The revolution and was not unexpected in the post-Mas heen a recurrent theme since the early ACFTU tract affirmed as a foundation principle: "to of modernisation. Indeed, one launch labour emulation drives, strengtion principle: "to organize the workers and staff to over-fulfilment of the state's production plans" (Fr discipline and ensure the fulfilment or

In the post 1978 era, trade unions at all levels (Foreign Languages Press, p. 26). drives. Senior officials attended ministerial product quality improvement in productivity 
exemplary workers congress members solicited orders for their enterprise's products in a nationwide sales campaign. In one favourably reported case, hotel workers adopted the slogan "customers are gold" and used their leisure time to pick up potential guests at bus and train stations (Workers daily, 23 December, 1981).

The most institutionalised form of trade union productivity fostering, however, was the labour emulation campaign which aimed to produce the "model worker". Such campaigns commenced soon after official restoration in the building and power industries in 1978 and 1979 and later in textiles. By 1981, according to ACFTU Research Department statistics, over half the urban workforce had been designated as model workers (Xue, 1982, p. 709). There were various grades within the model category, affording different levels of material and ceremonial recognition. In the former category, reception in Beijing, involving travel, banquets and absence from the shopfloor, was offered to the most successful. In the latter category, one more recent innovation was the award of ACFTU May Day Labour Medals to the top 1000 or so achievers (China daily, 1 May, 1985).

The criteria for model individual worker and work group status were continually refined and promulgated by the ACFTU. The quantitative movement forward necessary to qualify as a model started from the shopwide benchmark production norm which was expressed as an output/man hours ratio and caracteristically calculated by a committee of production managers, wage administrators and ordinary workers often on the basis of time and motion observations (Socialist industrial enterprise management, 1980, p. 308). But the committees which awarded model worker status were trade union sponsored. Labour emulation was more or less the only field in which the ACFTU and its shopfloor organisations exercised nearly exclusive discretion.

Qualitative achievements and inventive skills as well as physical productive accomplishments were also assessed and applauded. ACFTU literature familiarised workers with the career of its chairman who as a former model worker had invented the "Ni Zhi Fu Machine tool bit". Statistics on workers suggestions and technical inventions were collected by shopfloor organisations for publication by the ACFTU (BBC, 18 October, 1983). The ACFTU's tested role as a work performance and productivity booster in the post-Mao economic expansion programme underwrote official sponsorship of the trade unions.

\section{Wage bargaining and disputes}

Formally, there has never been an institutional role for Chinese trade unions in wage determination. Pay demands have been viewed by Party and State central planners as manifestations of unworthy "economism" and have not been dignified by the establishment of special committees or tribunals for their settlement. The bedrock of urban wage determination in the post revolutionary era has been a national pay grade scale varied by centrally determined regional loadings and plant level bonuses.

In the recent era of economic reform, bonuses have come to play a greater part, sometimes amounting to the equivalent of 4 or 5 months of standard wages over an annual period. The June 1985 wage reform moved further away from grade seniority toward performance linked bonuses. A "floating" bonus system was encouraged whereby individual enterprise bonus funds were geared to the profits of that enterprise. But not uncharacteristically, this reform was soon balanced and partially retracted; a frequent outcome in the modernisation programmes. Within months, bonus fund taxes, payable by the enterprise, were progressively increased, cutting back the funds for plant level bonus payments (Red flag, 1 February 1985; Halfmonthly talks, 1985).

Wage regulations have been characteristically gazetted under the imprimateur of the State Council, the Economic Planning Commission and the Bureau of Labour; an organisation which reappeared in 1976 after its Cultural Revolution dissolution. In their published terms. such regulations were not the product of collective bargains or arbitrated awards.

But at both enterprise level and above, trade union involvement can be identified in wage consultation, deliberation and authorisation. At enterprise level, workers' congresses sometimes exercised their constitutional powers to reject or approve proposed individual promotions and hence pay grade movements. Shopfloor trade unionists also generated pressures for bonus awards or non-awards to specific groups. In the Special Economic Zones. trade union officials participated in wage determination by assisting in the negotiation of individual employee/management bargains, a traditional role of the pre- and nonrevolutionary Chinese trade societies. 
Beyond the enterprise level, senior trade union officials moved in the milieu of central planners and executives where national wages policy was made. Particularly after the volume of price and wage reforms grew in the early 1980 s, ACFTU officials participated in inter bureaux meetings and delegate conferences on pay and grading (Beijing review, 13 February, 1984, p. 18).

Although the ACFTU could not be ignored on the wage determination landscape, its role was difficult to assess, and fell far short of formal negotiating rights of any kind. Rather, middle ranking and junior trade union officials conceived of their proper role as facilitating and monitoring the implementation of wage reform, justifying trade unionism as a supporting agency of the modernisation programmes.

In grievance settlement, there were similarly no universal, formalised channels. Institutionalised bipartisan arrangements would imply a constant antagonistic potential and a non-unitary status for the Chinese workplace at odds with both the post-revolutionary tradition and the Confucian master-servant relationship on which the pre-revolutionary worker associations and guilds were based. After a brief period of specific legality as Article 45 of the 1978 Constitution, the right to strike reverted to ambivalence. Workplace grievances over factory housing allocation, bonuses and dismissals could and did go through the multi-step involvement of higher echelons of trade union officialdom, the Party and industrial administration. But the public specification of detailed grievance procedures was not thought appropriate.

Since "labour protection" was an historic and recognised trade union function, officialdom was most sympathetic to health and safety disputes which could be interpreted as the unequivocal imposition of hazards on workers. One newly elected member to the ACFTU's Xth National Congress Executive Committee had been a shopfloor leader fired and re-instated after a protracted dispute over safety in a printshop (ibid p. 20). But relative to labour emulation, and health, education and welfare, the "heart" concerns of Chinese organised labour, the ACFTU devoted minor attention to matters of belligerence such as wages and workplace grievances.

Nor did staff turnover and employment loss associated with the marketisation policies confront the unions as issues. The impact of smashing the "iron rice bowl" (i.e. removing job security) was cushioned by the growth of demand for labour. Aggregate urban employment grew from 94.91 million in 1978 to 115.18 million in 1983 (Beijing review, 27 August, 1984, pp. 1819). At enterprise level, the 1983 joint Economic Commission and Ministry of Personnel Notice on Stopping Wages was not rigorously implemented in practice. One report 3 years later cited a pilot regional grouping of 20 enterprises where some 43 workers had had their pay terminated for periods of between 1 and 5 years since 1983. Some of these individuals were reported to have prospered as entrepreneurs in the market sector beyond the state enterprise system (China legal journal, 8 January, 1986). Job security has not yet developed as a source of mass grievance warranting official and ACFTU attention.

\section{Conclusion}

In the period 1973-1986, the record of institutional consolidation and the return to traditional activities by the trade unions can be interpreted as an element of a new post Cultural Revolution cycle in the oscillation of political and industrial policies noted by commentators (Andors, 1977). The process of moderate and pragmatic reform was officially begun in 1973 and is still the orthodoxy in labour affairs.

After the Cultural Revolution, the trade unions became the monitors of official policy and conductors of grievances to decision makers. The ACFTU acted to filter out and set straight certain types of personnel problems exacerbated by the harsh implications of modernisation. As changes in payment systems, discipline, labour allocation and work techniques accelerated, the trade unions pinpointed areas of labour friction.

The ACFTU and its enterprise level organisations addressed the technical problems of greater productivity and the creation of an education, entertainment and welfare infrastructure to cushion the impact of change on industrial workers. Moreover, the establishment of workers' congresses offered a fresh symbol of worker participation and shopfloor democratisation as well as a practical check on abuses of prerogative.

The ACFTU guaranteed its continued state of health by avoiding crises with the Party over the question of "economism" and the current operative status of the classical Marxian model "transmission-belt" relationship between Party, trade unions and workers which had marked 
the early post revolutionary era. Cordial relations with the rest of the Chinese establishment and a compliant and uncontroversial role in the campaigns and programmes of the Four Modernisations ensured the restoration and progress of the ACFTU.

But the prospects for the later 1980s are not necessarily quite the same. The creation of large and instant trade union membership has already been largely accomplished although some further scope lies in the "market" enterprises outside the state sector which have become recruitment targets. Workers congresses have also been organised in most mainstream enterprises. with the consequence that ACFTU emphasis has shifted to encouraging concrete results from congresses already in place. As to changes in trade union activities, the fragmentation of earnings levels due to bonus schemes and the growth of formal contractual arrangements in labour allocation have begun to show potential as problem areas to which. one might speculate, the unions in future might be called to respond.

Overall. the cycle of moderate pragmatism in trade union affairs has yet to show firm signs of exhaustion. A future resurgence of agrarian radicalism and a shift of resources away from urban and industrial employment would signal the start of a new phase in which the supportive framework for the growth of the ACFTU and "bureaucratic" trade unionism might be eroded.

\section{References}

ACFTU (1980) The democratic management of Chinese enterprises.

Andors. S (1977) (China's industrial revolution London, Martin Robertson.

Bartke. W (1981) Whose who in China New York. Sharp.

Beijing review (1981) $24: 36$.

Beijing review (1984) $27: 3$.

Beijing review (1984) $27: 7$.

Beijing review (1984) $27: 35$.

British Broadcasting Corporation Summaries of world broadcasts.

$\mathrm{FE} / 5952 / \mathrm{B} 11 / 17$ - 26 October 1978

$\mathrm{FE} / \mathrm{W} / 1070 / \mathrm{A} / \mathrm{i}-20$ February 1980

FE/7096/B11/15 - 6 August 1982

FE/7180/B11/27 - 11 November 1982

$\mathrm{FE} / 7470 / \mathrm{B} 11 / 9$ - 18 October 1983

$\mathrm{FE} / 7469 / \mathrm{B} 11 / 1$ - 21 October 1983

China daily 1 May 1985; 27 August 1985.

China directory (1980) Tokyo, Radio Press Inc.

China legal journal (Zhongguo Fazhibao) 3 January 1986.

China reconstructs (June 1980) Liu Shao Qi - Justice Finally done xxxix (6) : 9-15.

Chinese trade unions (April 1982), 2.

Crouch, H (1979) The Indian working class Agmer, Sactim.

Foreign Languages Press (1956) Trade unions in People's China Beijing.

Guo. Y (1980) In Socialist enterprise management (Shehuizhuyi qiye guanli) Beijing.

Half Monthly Talks (Ban Yue Tan) (1985), 16.

Henley, J and Chen, P (1981) A note on the appearance, disappearance and re-appearance of dual functioning trade unions in the People's Republic of China British Journal of industrial relations $\mathbf{x i x}$ (i) : 87-93.

Hoffman, C (1974) The Chinese worker Albany, State University of New York Press.

International Labour Conference (1983) Provisional Record 96th Session Geneva, ILO Printer. 


\section{Richard Morris}

Kahan, A and Ruble, B (1979) (Eds) Industrial labour in the USSR London, Pergammon.

Littler, C (1983) The significance of trade unions in China Industrial relations journal 14 (4):3142.

NG, S (1984) One brand of workplace democracy: the workers' congress in the Chinese enterprise Journal of industrial relations 26 (i).

Red Flag (Hong Qi) 1 February 1985, 3.

Shanghai College of Finance and Economics and Shanghai Academy of Social Sciences (1980) Socialist industrial enterprise management (She hui zhuyi gongye qiye guanli) Shanghai.

To, L (1983) The All-China Federation of Trade Unions in the cultural revolution Australian journal of politics and history 29 (i) : 50-62.

Tsien, T (1979) In Encyclopaedia of labour law The Netherlands, Klumer.

Workers daily (Gongren Ribao) 18 November 1981; 17 December 1981; 23 December 1981; 6 January 1982.

Xue, M (1982) (Ed) Almanack of China's economy Hong Kong, Modern Cultural Company Limited.

The Chinese names of Chinese language only texts are placed in brackets. 